\title{
Global endometrial ablation: A modern day solution to an age-old problem
}

\author{
H. Morgan, A.P. Advincula *
}

Department of Obstetrics and Gynecology, University of Michigan Medical Center, USA

\section{KEYWORDS \\ Endometrial ablation; Dysfunctional uterine bleeding; Gynecologic surgery}

\begin{abstract}
Menorrhagia remains a significant health issue for women worldwide. Traditionally hysterectomy has been the treatment of choice when excessive menstrual bleeding remains unresolved by hormonal manipulation. In an attempt to provide a less invasive alternative to hysterectomy, traditional techniques such as rollerball endometrial ablation were developed 20 years ago. Although extremely effective, they possessed the potential of significant intra-operative risks and their success depended on high technical proficiency of the surgeon. As surgery and technology evolved, second generation endometrial ablation devices were developed which demonstrated improved safety and efficacy rates that paralleled traditional treatments. Since 1997, the Food and Drug Administration (FDA) has approved five such devices for use in the United States. Each possesses a unique technology profile with supporting level I evidence that allows for the treatment of a wide variety of uterine anatomy.

(C) 2006 International Federation of Gynecology and Obstetrics. Published by Elsevier Ireland Ltd.
\end{abstract}

\section{Introduction}

Approximately $20-25 \%$ of healthy premenopasual women have abnormal uterine bleeding. The prevalence of abnormal uterine bleeding increases with age, peaking at about the fifth decade of life. Approximately 600,000 hysterectomies are

\footnotetext{
* Corresponding author. Minimally Invasive Surgery Program and Fellowship, Department of Obstetrics and Gynecology, University of Michigan Medical Center, L 4000 Women's Hospital, 1500 East Medical Center Drive, Ann Arbor, MI 48109, United States. Tel.: +1 734764 8429; fax: +1 7346479727 .

E-mail address: aadvincu@umich.edu (A.P. Advincula).
}

performed annually each year in the United States and it is estimated that $20 \%$ to $25 \%$ of these are to relieve excessive menstrual bleeding unresolved by medical management [1]. Data from 19881993 indicate that more than one quarter of women will have a hysterectomy by the age of 60 . The highest hysterectomy rates are for women ages $40-44$ [2].

Alternative methods to hysterectomy have been explored for many years. Endometrial ablation, defined as the elimination of the endometrium by thermal energy or resection, was introduced in the 1980 's as an alternative for patients with abnormal uterine bleeding. DeChernery and Polan described 
the use of a urologic loop electrode to treat women with menometrorrhagia [3]. Soon thereafter, rollerball ablation was introduced in Japan in 1988 and in the United States in 1989 [4,5]. Rollerball ablation soon evolved into the most widely used hysteroscopic ablation technique because of its ease of use, and decreased risks of complications. In 1990, a modification using a continuous-flow resectoscope and low-viscosity distention fluid to perform transcervical resection of the endometrium was described [6]. These techniques became known as first generation endometrial ablations. A Cochrane database analysis of first generation endometrial ablations versus hysterectomy showed that they were a reasonable alternative to hysterectomy with high efficacy and satisfaction rates [7]. However, these first generation systems were highly operator skill dependent, with operative risks of uterine perforation, cervical laceration and intra-operative fluid overload that resulted in electrolyte abnormalities.

The second generation endometrial ablation devices were introduced in the early 1990's as alternatives to the first generation devices. They were developed in an effort to simplify the ablative procedure but provide efficacy that parallels traditional hysteroscopic modalities. The second generation devices were intended to involve less skill and training, and ideally be able to be performed under local anesthesia. There have been 5 second generation devices that have been approved by the Food and Drug Administration (FDA) for use in the United States. The initial data on these five devices were reported as case series and observational studies (level III evidence). In order to gain FDA approval, these second generation devices were put through randomized controlled trials that compared them with traditional hysteroscopic rollerball (RB) ablation. This paper will review the current level I evidence obtained from randomized controlled trials that support the safety and efficacy of these second generation ablative devices.

In order to better interpret the following review of second generation global endometrial ablation devices, it is important to define menorrhagia. It is often defined as menstrual bleeding in the ovulatory woman that lasts longer than 7 days, or menstrual blood loss exceeding $80 \mathrm{ml}$. Many of the following studies in turn utilize a validated diary system known as a pictorial bleeding assessment chart (PBAC) to help define menorrhagia. It is a scoring system in which a score of 100 correlates with menstrual flow of approximately $80 \mathrm{ml}$ [8]. Patients enrolled in studies are typically defined as having menorrhagia with scores greater than 150 and success rates are often defined as a score less than 75 . Success rates as they relate to changes in bleeding patterns will be discussed in the cited studies supporting these various ablation devices in addition to satisfaction rates and complications. An overview of the technological aspects of each device will precede a review of the level I literature.

Candidates for any global endometrial ablation are women with abnormal uterine bleeding refractory to medical therapies and who have endometrial biopsy proven absence of an endometrial neoplasm. Typically, it is also required that the uterine cavity be free of any endometrial polyps or leiomyomata and that it be less than $10-12 \mathrm{~cm}$ in length, although for many of the second generation devices, these are not necessarily exclusionary. A diagnostic hysteroscopy or saline infusion sonography is usually performed prior to an ablative procedure in order to confirm an appropriate endometrial cavity.

\section{ThermaChoice Uterine Balloon Therapy (UBT) system}

\subsection{Device}

The concept of a thermal balloon ablation system was first described in 1994 [9]. Several years later in 1997, the Gynecare ThermaChoice Uterine Balloon Therapy System became the first global endometrial ablation device approved by the FDA. Since its inception, not only has the UBT system shown continued device improvements, but its safety and efficacy has been demonstrated with both short and long term results.

This method of global endometrial ablation relies on a balloon that is filled with fluid (5\% dextrose and water) which in turn combines heat and pressure within the uterine cavity to achieve an effect. The balloon is designed to be able to take up the shape of the endometrial cavity for better coverage. The ThermaChoice I system (Gynecare, Division of Ethicon, Somerville, NJ) is the introductory model, and consist of a controller, and a disposable $16 \mathrm{~cm}$ long, $4.5 \mathrm{~mm}$ diameter catheter with a latex balloon attached to its distal end. Minimal cervical dilation is required. The balloon is tested for leaks, and then primed by inflating it with several milliliters of $5 \%$ dextrose and water. The balloon is then deflated to a pressure of approximately negative $180 \mathrm{~mm}$ of $\mathrm{Hg}$. The catheter is then inserted into the uterine cavity and inflated to approximately $180 \mathrm{~mm}$ of $\mathrm{Hg}$, 
at which point the fluid is heated to $87{ }^{\circ} \mathrm{C}$ for a total treatment time of $8 \mathrm{~min}$.

The ThermaChoice II system, introduced in 1998, improved upon the first generation device by providing a small impeller inside the balloon to circulate fluid during the procedure. In addition, the balloon material was changed to silicone from latex. The ThermaChoice III system, introduced in 2004, had an additional modification to the silicone balloon for better coverage and expansion within the uterine cavity.

\subsection{Literature}

Of all the second generation endometrial ablation devices, there has been the most experience with the ThermaChoice system in the United States. All of the randomized controlled trials for this method of ablation to date have been performed with the ThermaChoice I system.

A large multi-center randomized controlled trial of ThermaChoice I (UBT) versus rollerball (RB) ablation was performed in 1996, with results reported at the 1, 2, 3 and 5 year follow up intervals. Meyer et al. first reported the 1 year results [10]. 255 women with a PBAC score greater than 150 were randomized at a 1:1 ratio to UBT versus $\mathrm{RB}$ ablation with 239 available for evaluation at year's end. There was no medicinal pretreatment regimen administered however a 3 min curettage using a $5 \mathrm{~mm}$ suction curette was completed before ablation by either technique. $80.2 \%$ of the UBT patients and $84.3 \%$ of the RB patients reported a return to normal bleeding or less (PBAC score of less than 100). On the other hand, a greater percentage of women in the RB group $(27.2 \%)$ compared with the UBT group $(15.2 \%)$ were amenorrheic at 1 year. Despite these findings, $85.6 \%$ of the UBT patients and $86.7 \%$ of the RB patients were highly satisfied with their results. Only 5 hysterectomies were performed after treatment prior to 1 year follow up (2 UBT, 3 $\mathrm{RB})$. There were four intra-operative complications in the RB arm and none in the UBT arm (Table 1).

Grainger et al. reported a 2 year follow up data on 227 evaluable patients [11]. 89.1\% of the UBT patients and $90.4 \%$ of the RB patients reported amenorrhea or eumenorrhea. 11 (8.9\%) hysterectomies were performed in the RB arm, and 4 $(3.0 \%)$ in the UBT arm. Satisfaction rates of $86.1 \%$ and $86.7 \%$ were seen in the UBT and RB arms, respectively. Loffer reported 3 year follow up data on 214 evaluable patients [12]. $93.0 \%$ of the UBT and $93.9 \%$ of the RB patients reported amenorrhea or eumenorrhea. $8(6.5 \%)$ of the UBT patients and $14(14 \%)$ of the RB patients had hysterectomies performed at 3 years. Satisfaction rates remained high at $95.6 \%$ and $94 \%$ for the UBT and RB patients, respectively. Loffer and Granger reported 5 year follow up data [13]. 147 patients were available for follow up of which 25 had undergone a hysterectomy, repeat endometrial ablation or dilation and curettage between years three and five. Of those 122 left for analysis, $95 \%$ of the UBT patients and $97 \%$ of the RB patients reported amenorrhea or eumenorrhea. 93\% of the UBT patients and $100 \%$ of the RB patients were satisfied with their procedure. Among the total population of 255 patients originally enrolled in the trial, 42 hysterectomies ( 21 UBT, 21 RB), 5 repeat endometrial ablations ( $3 \mathrm{UBT}, 2 \mathrm{RB}$ ), and

Table 1 ThermaChoice Uterine Balloon Therapy (UBT) system

\begin{tabular}{|c|c|c|c|}
\hline Author, patients & Efficacy findings & Complications & Reliability and validity issues \\
\hline $\begin{array}{l}\text { Meyer et al. ( } 1 \text { year data) } \\
\text { Grainger et al. ( } 2 \text { year data) } \\
\text { Loffer FD ( } 3 \text { year data) } \\
\text { Loffer et al. ( } 5 \text { year data) } \\
\text { ThermaChoice I (UBT) } \\
\quad \text { versus rollerball (RB) } \\
\quad \text { ablation } \\
N=255 \text { (study inception) } \\
\text { UBT }=131 \\
\text { RB }=124 \\
\text { Follow up: } 1,2,3 \text {, and } 5 \text { years }\end{array}$ & $\begin{array}{l}\text { UBT: } \\
1 \text { year: } 80.2 \% \text { reported normal } \\
\text { bleeding or less, } 15.2 \% \text { amenorrhea } \\
2 \text { year: } 89.1 \% \text { reported amenorrhea } \\
\text { or eumenorrhea } \\
3 \text { year: } 93 \% \text { reported amenorrhea } \\
\text { or eumenorrhea } \\
5 \text { year: } 95 \% \text { reported amenorrhea } \\
\text { or eumenorrhea } \\
\text { RB: } \\
1 \text { year: } 84.3 \% \text { reported normal } \\
\text { bleeding or less, } 27.2 \% \text { amenorrhea. } \\
2 \text { year: } 90.4 \% \text { reported amenorrhea } \\
\text { or eumenorrhea. } \\
3 \text { year: } 93.9 \% \text { reported amenorrhea } \\
\text { or eumenorrhea. } \\
5 \text { year: } 97 \% \text { reported amenorrhea } \\
\text { or eumenorrhea. }\end{array}$ & $\begin{array}{l}4 \text { intra-operative } \\
\text { complications with } \\
\text { RB ablation: } \\
1 \text { cervical laceration } \\
1 \text { uterine perforation } \\
2 \text { fluid overload } \\
\text { UBT (none) }\end{array}$ & $\begin{array}{l}\text { Study was not blinded } \\
88 \% \text { available for } 2 \text { year } \\
\text { follow up data } \\
83 \% \text { available for } 3 \text { year } \\
\text { follow up data } \\
57 \% \text { available for } 5 \text { year } \\
\text { follow up data }\end{array}$ \\
\hline
\end{tabular}


one $D$ and $C(R B)$ were performed by year 5 (Table 1).

van Zon-Rabelink et al. performed a randomized controlled trial comparing UBT to RB ablation [14]. 137 patients were randomized at a 1:1 ratio to UBT versus RB ablation. Patients had menorrhagia based on a PBAC score of greater than 185. All patients were treated with goserelin acetate 6 and 2 weeks preoperatively. The primary endpoint was a reduction in PBAC score with the definition of a study success being a PBAC score of less than 185 and a failure defined as continued menorrhagia with a PBAC score of greater than 185 . This differed from many other studies cited in this review which define success as a PBAC score of less than 75 (a marked reduction in bleeding). Success rates were not statistically significant at 12 or 24 months postoperatively, and patient satisfaction rates were also non-significant. They found a higher risk for intra-operative complications with the 60 RB patients ( 3 uterine perforations and 3 cervix lacerations) that was statistically significant. Both the UBT and RB arms had intra-operative technical complications. Five of the 77 UBT procedures were complicated by control device error and four procedures were not able to attain sufficient intrauterine pressure. Six of the $60 \mathrm{RB}$ procedures were complicated by a nonfunctioning rollerball or fracture of the rollerball tip (Table 2) [15].

Advantages of the ThermaChoice Uterine Balloon Therapy System are its ease of use, need for minimal cervical dilation, and applicability to the office setting. Pretreatment of the endometrium is also optional. This system has also been used the most extensively in the United States with long term data confirming its safety and efficacy. Additionally, this method of global endometrial ablation is the only product that is FDA approved for use with the Essure ${ }^{\circledR}$ system for permanent contraception. The disadvantages are the blind nature of the procedure without any hysteroscopic visualization and the requirement of an anatomically normal cavity. In addition, the balloon may not be able to fully ablate the residual endometrial tissue in the cornual regions of the uterus. Finally, the study by van Zon-Rabelink et al. also demonstrated that technical failure of either the controller or the disposable balloon catheter can compromise or sabotage the entire procedure.

\section{Hydro ThermAblator (HTA) system}

\subsection{Device}

The Hydro ThermAblator System (Boston Scientific, Natick, MA) is a global endometrial ablation device developed in 1997, and approved by the FDA in April 2001. This system delivers heated USP 0.9\% saline in a closed-loop system to the uterine cavity under direct hysteroscopic guidance. Preliminary studies on hysterectomy specimens demonstrate that a 10 min circulation time at $90{ }^{\circ} \mathrm{C}$ achieves a depth of necrosis from 3 to $4 \mathrm{~mm}$ throughout the endometrial cavity in a uniform distribution [16]. Endometrial pretreatment is considered essential since there is no endometrial compressive effect during the treatment.

For this procedure, the cervix is dilated to $8 \mathrm{~mm}$ to accept a $7.8 \mathrm{~mm}$ insulating sheath. This houses a $3 \mathrm{~mm}$ hysteroscope with inflow and outflow channels which are connected to a microprocessorbased control system that contains a heating element. The uterine cavity is distended with room temperature normal saline. A tenaculum on the cervix can assist with creating a leak-proof seal around the instrument sheath. A 3 I saline bag is elevated to $115 \mathrm{~cm}$ above the uterus which creates a net intrauterine pressure of approximately 50 to $55 \mathrm{~mm} \mathrm{Hg}$. This hydrostatic pressure is well below the threshold for opening the fallopian tubes. A diagnostic hysteroscopy can be performed at this time. The saline is then heated to $90{ }^{\circ} \mathrm{C}$ for the actual treatment. This fluid is infused and returned to the controller via a peristaltic pump in a closedloop system. The average treatment time is $10 \mathrm{~min}$.

Table 2 ThermaChoice Uterine Balloon Therapy (UBT) system

\begin{tabular}{llll}
\hline Author, patients & Efficacy findings & Complications & Reliability and validity issues \\
\hline van Zon-Rabelink et al. & UBT: & Higher risk of intra-operative & Study was not blinded \\
ThermaChoice I (UBT) & Success: 78\% & complications with RB ablation: & Definition of study success \\
$\begin{array}{l}\text { versus rollerball } \\
\text { (RB) ablation }\end{array}$ & Patient satisfaction: $80 \%$ & 3 uterine perforations & \\
$N=137$ & RB: & 3 cervix lacerations & \\
UBT $=77$ & Success: 76\% & 1 electrolyte imbalance \\
RB $=60$ & Patient satisfaction: 75\% & 1 suspicion of perforation \\
Follow up =2 years & & UBT (none) & \\
& & Technical complications with RB $=10 / 62$ & \\
& & Technical complications with UBT $=13 / 77$ \\
\hline
\end{tabular}


There is an automatic shutdown if there is a loss of $10 \mathrm{ml}$ or an increase of $20 \mathrm{ml}$ of fluid.

\subsection{Literature}

Corson performed a multi-center prospective randomized controlled trial which compared endometrial ablation using the Hydro ThermAblator (HTA) to rollerball (RB) ablation [17]. 276 patients with PBAC's greater than 150 for 3 months, with no month having a score below 100 were enrolled in the study. 187 were randomized to the HTA arm, and 89 were randomized to the RB arm. All patients received one pre-treatment dose of depot leuprolide acetate $7.5 \mathrm{mg}$. Success was defined as a PBAC score of less than 75 at 12 months. This was $77 \%$ in the HTA group and $82 \%$ in the RB group, with no statistical significance between the two groups. Amenorrhea rates at 1 year were $40 \%$ for the HTA group, and $51 \%$ for the RB group, again with no statistical significance between the two groups. Two the HTA participants had hysterectomies during the 12 month follow up. One was for increasing symptoms from an enlarging fibroid, and another was for unclear reasons. There were two cervical lacerations in the $\mathrm{RB}$ group, one of whom required hospitalization for fever, nausea, vomiting and diarrhea that was attributed to gram-negative septicemia. There were none in the HTA group. Two patients in the HTA group sustained first-degree burns, one on the upper thigh and the other on the buttocks from prolonged contact with the tubing that carries heated saline from the control unit to the hysteroscopic sheath. There were five cases of hematometra in the RB group and only two in the HTA group (Table 3).
Goldrath reported the 3 year clinical follow up of these same study participants [18]. At 36 months, amenorrhea rates, reduction of bleeding to normal levels or less, and patient satisfaction were tracked with rates in the HTA group of $53 \%, 94 \%$, and $98 \%$ and in the RB group of $46 \%, 91 \%$, and $97 \%$, respectively (Table 3 ).

A key advantage of this global endometrial ablation device is that it is the only technique guided hysteroscopically throughout the entire procedure. Additionally, the HTA system is able to treat the entire endometrial surface, including those asymmetrically shaped or those distorted by leiomyomas, as long as both tubal ostia are visible on hysteroscopic examination. HTA can also be applied to the office setting. Disadvantages are the need for cervical dilatation, longer treatment times, the risk of thermal burns to the vagina, cervix and/or vulva, and the fact that hot water stimulates pain [19]. Although pretreatment of the endometrium is advocated in the pivotal FDA trial, it is not considered mandatory.

\section{Her option cryoablation therapy system}

\subsection{Device}

The technique of cryotherapy has been shown to achieve cell death through chemical damage or intracellular ice formation. Historically, the use of cryoablation to treat the endometrium was first described in 1967 by Cahan and Brockunier [20]. They reported circulating liquid nitrogen at -80 to $-100{ }^{\circ} \mathrm{C}$ through a $30 \mathrm{~cm}$ long cryosurgical probe

Table 3 Hydro ThermAblator (HTA) system

\begin{tabular}{llll}
\hline Author, patients & Efficacy findings & Complications & Reliability and validity issues \\
\hline Corson SL & HTA: & 2 cervical lacerations in RB group & Study was not blinded \\
Hydro Thermablator (HTA) & 1 year: & (one complicated by septicemia) & \\
$\begin{array}{l}\text { versus rollerball (RB) ablation } \\
\text { Success: } 77 \%\end{array}$ & 2 patients with first-degree & Amenorrhea: $40 \%$ & burns in HTA group \\
HTA $=187$ & 3 year: & Cases of hematometra: \\
RB $=89$ & Amenorrhea: $53 \%$ & 2 (HTA) \\
Follow up=1 year & Patient & 5 (RB) \\
Goldrath NH & satisfaction: $98 \%$ & 7 incomplete HTA procedures \\
(3 year follow up on same patients) & RB: & secondary to technical difficulties \\
& 1 year: & \\
& Success: $82 \%$ & \\
& Amenorrhea: $51 \%$ & \\
& 3 year: & \\
& Amenorrhea: $46 \%$ & \\
& Patient & \\
& satisfaction: $97 \%$ & \\
\hline
\end{tabular}


shaped to a number six Hegar dilator. Menstrual flow was reduced in five out of the six study participants. Droegemueller et al. reported using Freon instead of liquid nitrogen in 16 patients with menorrhagia in 1971 [21]. 10 out of the 16 study participants were successfully amenorrheic during the 6-8 week follow up interval. Several decades later, CryoGen Inc. developed the Her Option Cryoablation Therapy System (American Medical Systems, Minnetonka, Minnesota) which was approved by FDA for endometrial ablation in April 2001.

A $5 \mathrm{~mm}$ cryoprobe is inserted through the cervix into the uterine cavity. The compressor system, which is hermetically sealed, drives the unit as a coolant is re-circulated and replenished through the system. This function is based on the JoulesThompson principal that states that pressurized gas produces a cooling effect when expanded through a small orifice. An iceball with temperatures ranging from $-100{ }^{\circ} \mathrm{C}$ to $-120{ }^{\circ} \mathrm{C}$ eventually forms around the probe. Transabdominal ultrasonography follows the growth of the ice ball, and the procedure is stopped when it approaches the uterine serosa. The ice front is identified on ultrasound by its echogenicity and shadowing behind it. The endometrial ablation process begins at the fundus and then the cornua. Tissue necrosis lags approximately $3-4 \mathrm{~mm}$ behind the ice front, because the temperature at the edge of the iceball is approximately $0{ }^{\circ} \mathrm{C}$, which is nondestructive to tissue. Tissue necrosis occurs at $-15{ }^{\circ} \mathrm{C}$ to $-20{ }^{\circ} \mathrm{C}$ [22]. The entire procedure takes between 10-20 min.

\subsection{Literature}

The pivotal prospective, randomized controlled trial of cryoablation versus rollerball ablation that helped with FDA approval was published by Duleba et al. [23]. 279 women with excessive uterine bleeding characterized by PBAC's greater than 150 were enrolled in the study, with 193 women randomized to the cryoablation arm, and 86 women randomized to the rollerball ablation arm. All patients received pretreatment with leuprolide acetate $3.75 \mathrm{mg}$ intramuscularly. The cryoablations were performed with the Her option system under transabdominal ultrasound guidance. The freeze pattern consisted of a four-minute freeze with the probe tip in one cornual area, and a six-minute freeze in the contralateral cornual area. Patients were excluded if they had a uterine cavity greater than $10 \mathrm{~cm}$ or leiomyomas greater than $2 \mathrm{~cm}$. A success was defined as the patient reporting a decrease in the PBAC score to less than $75.77 .3 \%$ of the cryoablation patients, and $83.8 \%$ of the rollerball patients were a study success, with no statistical significance between the two treatment arms in terms of study success, improvement in pain, mood and PMS symptoms. Interestingly there was a significantly decreased amount of anesthesia required for the endometrial cryoablation compared to the rollerball ablation. The procedure was well tolerated with patients reporting mild cramping and mild vaginal discharge. Townsend et al. reported a 24 month follow up on these same study participants [24]. 94\% of women in the cryoablation arm reported no abnormal uterine bleeding after 24 months, and $93 \%$ in the rollerball ablation group reported no abnormal uterine bleeding after 24 months. $7 \%$ of the cryoablation and $8.1 \%$ of the rollerball ablation patients proceeded to hysterectomy at this time interval. A limitation of the follow up study was the fact that the authors were only able to receive information on 94 cryoablation patients, and 43 rollerball arm patients (Table 4).

Advantages of the cryoablation system include the minimal cervical dilation required for the procedure, the lack of need for distension media, and less pain due to the analgesic effects of cryotherapy. As a result, this method of endome-

Table 4 Her option cryoablation therapy system

\begin{tabular}{llll}
\hline Author, patients & Efficacy findings & Complications & Reliability and validity issues \\
\hline $\begin{array}{l}\text { Dubela et al. (pivotal } \\
\text { trial for FDA approval) }\end{array}$ & Cryoablation: & $\begin{array}{c}1 \text { year: } \\
\text { with RB ablation }\end{array}$ & $\begin{array}{l}\text { Study was not blinded } \\
\text { from only } 94 \text { cryoablation }\end{array}$ \\
$\begin{array}{l}\text { Cryoablation versus } \\
\text { rollerball (RB) ablation }\end{array}$ & Amenorrhea: $27.6 \%$ & patients, and 43 RB patients \\
$N=279$ & Success: $77.3 \%$ & & \\
Cryoablation =193 & 2 year: & \\
RB=86 & No abnormal uterine bleeding: $94 \%$ & \\
Townsend et al. (2 year & Satisfaction: $91 \%$ & \\
follow up of same patients) & Rollerball: & \\
& Amear: & \\
& Success: $83.8 \%$ & \\
& 2 year: & \\
& No abnormal uterine bleeding: $92 \%$ & \\
& Satisfaction: $88 \%$ & \\
&
\end{tabular}


trial ablation lends itself well to office-based applications. Although pretreatment of the endometrium was done in the pivotal FDA trial, it is not necessary. The ability to visualize the advancing ice front in real time under ultrasound guidance may be considered an advantage however the need for an ultrasound machine may also be looked upon as a disadvantage. Other disadvantages of this system are the lack of direct visualization of the uterine cavity during the treatment process, longer treatment times, and the absence of data regarding the use of this technology in uteri with intracavitary lesions.

\section{NovaSure}

\subsection{Device}

The NovaSure device (Cytyc, Mountain View, CA) is an impedance-controlled endometrial ablation system, approved by the FDA in September 2001. This technology uses bipolar radiofrequency (RF) energy to desiccate and evacuate endometrial tissue. The actual device uses suction to draw the endometrium toward a gold-plated bipolar mesh electrode and to remove any generated vapor.

During an actual procedure, the cervix is dilated to $8 \mathrm{~mm}$ and the protective sheath which contains the bipolar electrode array is introduced. Once the sheath is retracted, the preshaped bipolar electrode array expands in the uterine cavity. Prior to initiation of the ablation, an integrity check of the endometrial cavity is performed. This is an automatic safety feature that confirms uterine wall integrity by injecting carbon dioxide into the uterine cavity and testing that steady intrauterine pressure is achieved and maintained prior to the actual ablation process. Once successfully completed, bipolar RF energy is delivered to the endometrium up to $180 \mathrm{~W}$ until an impedance of $50 \Omega$ is reached. The power setting is based on the width and length of the endometrial cavity which is calculated beforehand. The system is designed to provide less coagulation to the cornua and lower uterine segment, and deeper necrosis to the rest of the endometrium. The average treatment time is $90 \mathrm{~s}$ however the procedure also self-terminates after $2 \mathrm{~min}$.

\subsection{Literature}

Cooper et al. compared the NovaSure endometrial ablation system to conventional rollerball (RB) ablation in the pivotal trial for FDA approval [25].
265 women with menorrhagia and PBAC scores of 150 or above for three consecutive months were enrolled in the study. Patients were randomized using a ratio of $2: 1$ to NovaSure versus RB procedure. There was no pretreatment administered. The authors reported a study success rate, defined as a PBAC score of less than 75 , in $88.3 \%$ of the NovaSure patients, and $81.7 \%$ of the RB patients. Reduction of bleeding to normal levels or less (PBAC score of 100 or less) and amenorrhea was reported in $90.9 \%$ and $41 \%$ of the NovaSure patients respectively versus $87.8 \%$ and $35 \%$ in the RB patients. The NovaSure procedure time was significantly less at $4.2 \mathrm{~min}$, compared to the RB time of $24.2 \mathrm{~min}$. Anesthesia requirements were also less in the NovaSure group, with local and/or IV sedation given alone in $73 \%$ of those patients compared with $18 \%$ of the RB patients. Finally, there were less intra-operative adverse events with the NovaSure system than with the RB approach with rates of $0.6 \%$ and $6.7 \%$ respectively. The only NovaSure event was a bradycardia episode after the device was inserted. In the RB group there were three uterine perforations, and three cervical lacerations. There were also significantly less postoperative events with the NovaSure system with rates of $13 \%$ versus $25.3 \%$ with the RB ablation system (Table 5 ).

Bongers et al. performed a double-blind, randomized, controlled trial comparing bipolar RF endometrial ablation (NovaSure) to balloon endometrial ablation (ThermaChoice) in a 2:1 ratio [26]. 126 women with menorrhagia and PBAC scores of 150 or more were included in the study. All patients had a normal uterine cavity measuring $6-11 \mathrm{~cm}$. Patients and their providers were unaware which arm they had been randomized to, and the ablations themselves were all performed by one provider. 83 patients were randomized to the NovaSure arm and 44 patients to the ThermaChoice arm. The authors reported significantly higher amenorrhea rates at 12 months in women who had the NovaSure ablation (43\%) than with the ThermaChoice procedure (8\%). The authors discussed this very low amenorrhea rate in the ThermaChoice arm, and hypothesized that this may have been lower than previously published data secondary to the double-blinded nature of the study. It should also be noted, however, that the pretreatment protocols for the ThermaChoice system were not followed. There was also a strong decrease in the PBAC score after treatment with the NovaSure than with the ThermaChoice arm. The authors also found a $90 \%$ patient satisfaction rate in the NovaSure arm, which was statistically significant when compared to the $79 \%$ patient 
satisfaction in the ThermaChoice arm. Operation time for the NovaSure was less than half the time for the ThermaChoice procedure. A potential pitfall to this study was the discovery of a technical failure in the NovaSure generator after treatment of the first 44 patients which required consideration during and modification of the statistical analysis (Table 5).

A significant advantage of the NovaSure system is the extremely short treatment and procedure time with no need for pretreatment of the endometrium. This approach has also been associated with minimal procedure related pain and as a result, the potential for office use exist. A unique feature of this device is the fact that the power level of each procedure is calculated taking account the size of the uterine cavity thereby allowing for customization with each patient. Disadvantages of this system include the need to dilate the cervix, the limitation of cavity size, and the lack of hysteroscopic guidance during actual treatment.

\section{Microsulis Endometrial Ablation (MEA)}

\subsection{Device}

The use of microwave energy to treat menorrhagia was first described in 1995 in the Lancet by Sharp et al. [27]. The commercialized entity became known as Microsulis Endometrial Ablation (Waterlooville, Hampshire, UK) and eventually gained FDA approval in September 2003. This approval included the ability to apply this method of endometrial ablation to patients with cavity measurements up to $14 \mathrm{~cm}$ and fibroid-associated cavity distortions of less than $3 \mathrm{~cm}$.

This novel technique consists of a control unit with foot pedal and a reusable hand-held device with an $8.5 \mathrm{~mm}$ diameter probe that is attached to an ergonomic handle. Microwave energy is generated by a magnetron and passed along the tip of the probe at a frequency of $9.2 \mathrm{GHz}$, at $30 \mathrm{~W}$. The absorption of microwave energy leads to generated heat which is conducted deeper into the tissue in order to destroy the basalis layer. Because thermal penetration occurs up to approximately $5-6 \mathrm{~mm}$, myometrial measurements should be determined in order to identify a possible risk of penetration to the serosal surface of the uterus during application. During an actual treatment, the cervix is dilated to 8-9 $\mathrm{mm}$, and the microwave probe is inserted to the level of the mid-fundus. The probe is activated by a foot switch and the temperature quickly rises to the therapeutic range from $70{ }^{\circ} \mathrm{C}$ to $80^{\circ} \mathrm{C}$ as the microwave energy is absorbed. The probe is then moved laterally to the bilateral cornua in a "sweeping motion" and then throughout the cavity so as to assure coverage. Intrauterine temperatures are monitored by thermocouplers on the external surface of the probe thereby providing real time monitoring of the treatment progress. The treatment time is approximately 3-4 min.

\subsection{Literature}

A review of several randomized controlled trials has shown excellent outcomes. Cooper et al. performed the pivotal randomized controlled multicenter trial comparing MEA to traditional rollerball ablation that helped gain FDA approval [28]. This study was unique in that women with uterine

\begin{tabular}{|c|c|c|c|}
\hline Author, patients & Efficacy findings & Complications & $\begin{array}{l}\text { Reliability and } \\
\text { validity issues }\end{array}$ \\
\hline $\begin{array}{l}\text { Cooper et al. (pivotal trial } \\
\text { for FDA approval) }\end{array}$ & $\begin{array}{l}\text { NovaSure: } \\
\text { Success: } 88.3 \%\end{array}$ & $\begin{array}{l}\text { NovaSure: } \\
\text { Patient with bradycardic episode }\end{array}$ & $\begin{array}{l}\text { Study was not } \\
\text { blinded }\end{array}$ \\
\hline $\begin{array}{l}\text { NovaSure versus rollerball } \\
\text { (RB) ablation }\end{array}$ & $\begin{array}{l}\text { PBAC < 100: } 90.9 \% \\
\text { Amenorrhea: } 41 \%\end{array}$ & $\begin{array}{l}\text { RB: } \\
3 \text { uterine }\end{array}$ & None \\
\hline$N=265$ & Mean procedure time: $4.2 \mathrm{~min}$ & perforations & \\
\hline NovaSure $=175$ & RB: & 3 cervical lacerations & \\
\hline $\mathrm{RB}=90$ & Success: $81.7 \%$ & 4 NovaSure procedures not performed: & \\
\hline Follow up $=1$ year & PBAC $<100: 87.8 \%$ & (2) uterine cavity $>10$ & \\
\hline Bongers et al. & Amenorrhea: $35 \%$ & (2) t-shaped uteri & \\
\hline $\begin{array}{l}\text { NovaSure versus } \\
\text { ThermaChoice ablation }\end{array}$ & $\begin{array}{l}\text { Mean procedure time: } 24.2 \mathrm{~min} \\
\text { NovaSure: }\end{array}$ & $\begin{array}{l}\text { Detection of technical failure of NovaSure } \\
\text { generator after treatment of } 44 \text { patients }\end{array}$ & \\
\hline$N=126$ & Amenorrhea: $43 \%$ & & \\
\hline NovaSure $=83$ & Patient satisfaction: $90 \%$ & & \\
\hline ThermaChoice $=43$ & ThermaChoice: & & \\
\hline $\begin{array}{l}\text { Follow up }=1 \text { year } \\
\text { Patient satisfaction } 79 \%\end{array}$ & Amenorrhea: $8 \%$ & & \\
\hline
\end{tabular}


Table 6 Microsulis Endometrial Ablation (MEA)

\begin{tabular}{llll}
\hline Author, patients & Efficacy findings & Complications & $\begin{array}{c}\text { Reliability and } \\
\text { validity issues }\end{array}$ \\
\hline $\begin{array}{l}\text { Cooper et al. (pivotal trial } \\
\text { for FDA approval) }\end{array}$ & MEA: & Two cervical lacerations & Study was not blinded \\
Microwave endometrial & ess than $75: 96.4 \%$ & in both the MEA and RB arms & \\
ablation (MEA) versus & Amenorrhea: $61.3 \%$ & \\
rollerball (RB) ablation & Treatment time: 3.45 min & \\
$N=322$ & RB: & \\
MEA $=215$ & Reduction in PBAC to & less than $75: 92.7 \%$ & \\
RB $=107$ & Amenorrhea: $51 \%$ & \\
Inclusion criteria: PBAC score & Treatment time: 20.26 min & \\
greater than 185 & & \\
Uterine cavities up to $14 \mathrm{~cm}$ & & \\
Fibroid less than $3 \mathrm{~cm}$ allowed (22\%) & & \\
Follow up=1 year & &
\end{tabular}

cavities up to $14 \mathrm{~cm}$ were included, and approximately $22 \%$ of the patients in the study had fibroids less than $3 \mathrm{~cm}$. All patients received pretreatment with leuprolide acetate depot 3-5 weeks prior to operative treatment. The primary outcome measure of this study was a reduction of the PBAC score to 75 or less, which defined a study success. In terms of evaluable patients, $96.4 \%$ of the microwave patients, and $92.7 \%$ of the rollerball patients were study successes. This study reported large amenorrhea rates for both the microwave and the rollerball arms of $61.3 \%$ and $51 \%$ respectively. The amenorrhea rate for the patients with fibroids in the MEA arm was $61.3 \%$ compared with $38.5 \%$ in the rollerball arm. Of note, this study did find that the microwave technique was more successful than rollerball ablation in treating patients with a body mass index (BMI) of 30 or greater (Table 6).

In another study, Cooper et al. compared microwave ablation to rollerball ablation in 263 women, randomized at a 1:1 ratio [29]. The primary outcome measure was patient satisfaction. They only included patients who had uteri that palpated to less than 10 weeks size on bimanual examination. All patients received preoperative endometrial preparation with goserelin $3.6 \mathrm{mg}$. All but 11 of the procedures were performed by two surgeons, each of whom had previously performed at least 50 rollerball ablations. $77 \%$ of the microwave and $75 \%$ or the rollerball patients were totally or generally satisfied with their treatments. Both techniques led to significant and equivalent reductions in pain and bleeding with amenorrhea rates of $40 \%$ for both groups. Of note, there were a number of postoperative complications in the rollerball group (Table 7).

Bain et al. reported 2 year follow up data on these same patients [30]. They reported that patients expressed greater satisfaction with the

Table 7 Microsulis Endometrial Ablation (MEA)

\begin{tabular}{|c|c|c|c|}
\hline Author, patients & Efficacy findings & Complications & $\begin{array}{l}\text { Reliability and } \\
\text { validity issues }\end{array}$ \\
\hline $\begin{array}{l}\text { Cooper et al. } \\
\text { Microwave endometrial } \\
\quad \text { ablation (MEA) versus } \\
\quad \text { rollerball (RB) ablation } \\
N=263 \\
M E A=129 \\
R B=134 \\
\text { Follow up }=1 \text { year } \\
\text { Bain et al. ( } 2 \text { year follow } \\
\text { up on same patients) }\end{array}$ & $\begin{array}{l}\text { MEA: } \\
\text { Mean operating time: } 11.4 \text { min } \\
1 \text { year: } \\
\text { Completely or generally satisfied: } 77 \% \\
\text { Amenorrhea: } 40 \% \\
2 \text { year: } \\
\text { Completely or generally satisfied: } 79 \% \\
\text { Amenorrhea: } 47 \% \\
\text { RB: } \\
\text { Mean operating time: } \\
15 \text { min } \\
1 \text { year: } \\
\text { Completely or generally satisfied } 75 \% \\
\text { Amenorrhea: } 40 \% \\
2 \text { year: } \\
\text { Completely or generally satisfied: } 67 \% \\
\text { Amenorrhea: } 41 \%\end{array}$ & $\begin{array}{l}\text { MEA system failures in } 4 \text { patients } \\
\text { One blunt perforation in each } \\
\text { group with one immediate } \\
\text { hysterectomy required in the RB group } \\
\text { Readmit of } 1 \text { RB patient with } \\
\text { pain leading to hysterectomy } \\
\text { Bleeding in } 5 \text { RB patients requiring } \\
\text { Foley bulb tamponade } \\
\text { Excess fluid deficit in } 1 \text { RB patient } \\
\text { requiring procedure to be aborted }\end{array}$ & $\begin{array}{l}\text { Study was } \\
\text { not blinded }\end{array}$ \\
\hline
\end{tabular}


microwave procedure, with $79 \%$ of microwave patients stating that they were either completely or generally satisfied with their results, compared to $67 \%$ of the rollerball patients. This was statistically significant. There was however no statistically significant difference in the rates of amenorrhea achieved between the two groups, with a rate of $47 \%$ in the microwave group, and $41 \%$ in the rollerball group. The need for further surgical intervention was similar for both arms of the study in that $11.6 \%$ of the microwave patients and $12.7 \%$ of the rollerball patients had hysterectomies performed during the 2 year follow up interval (Table 7).

Advantages of the MEA system include the short treatment time, and the ability to apply this method of endometrial ablation to patients with cavity measurements up to $14 \mathrm{~cm}$ and fibroidassociated cavity distortions of less than $3 \mathrm{~cm}$. Additional advantages of the system are the lack of requirement for uterine pretreatment as shown by Fortin et al. applicability to an office-based surgical practice, and the ability to perform hysteroscopic sterilization for permanent contraception following MEA procedures [31-33]. The need to dilate the cervix and the need to assess myometrial thickness with an ultrasound prior to treatment are disadvantages of this approach.

\section{Conclusion}

The evolution of endometrial ablation to its current state with second generation devices has allowed gynecologists to continue to manage menorrhagia in a minimally invasive fashion. An efficacy that parallels traditional hysteroscopic ablative techniques has been of paramount importance as seen in this review of the literature while also improving the safety profiles and ease of use of these devices. As a result of these changes, there has also been a trend towards the performance of these procedures in an office setting.

Critical to the successful use of these technologies is careful patient selection. A proper preoperative work up is necessary before initiation of any therapy for menorrhagia. Additionally, it is extremely important to understand the technical differences between devices since each one is designed for use in women with specific uterine anatomies. This is further evidenced by the wide variation in destructive modalities, treatment times, need for endometrial pretreatment, and complications encountered. In the end, a global understanding of these devices will allow gynecologic surgeons to enhance patient care with ad- vanced technologies that provide an alternative to hysterectomy.

\section{References}

[1] Carlson KJ, Nichols DH, Schiff I. Indications for hysterectomy. N Engl J Med 1993;328:856-60.

[2] Lepine LA, Hillis SD, Marchbanks PA, Koonin LM, Morrow B, Kieke B, et al. Hysterectomy surveillance - United States 1980-1993. MMWR 1997;46:1-16.

[3] DeChernery A, Polan ML. Hysteroscopic management of intrauterine lesions and intractable uterine bleeding. Obstet Gynecol 1983;61:392-6.

[4] Lin BL, Miyamoto M, Horikoshi H, Nakamura H, Iwata Y. The development of a new hysteroscopic resectoscope and its clinical applications on transcervical resection (TCR) and endometrial ablation (EA). Jpn J Gynecol Obstet Endosc 1988;4:56-61.

[5] Vancaillie TG. Electrocoagulation of the endometrium with the ball-end resectoscope. Obstet Gynecol 1989;74:425-7.

[6] Perino A, Cittadini E, Colacurci N, De Placido G, Hamou J. Endometrial ablation: principles and technique. Acta Eur Fertil 1990;21:313-7.

[7] Lethaby A, Shepperd S, Cooke I, Farquhar C. Endometrial resection and ablation versus hysterectomy for heavy menstrual bleeding. Cochrane Database Syst Rev 2005, 1.

[8] Higham JM, O'Brien PMS, Shaw RW. Assessment of menstrual blood loss using a pictorial chart. $\mathrm{Br} \mathrm{J}$ Obstet Gynaecol 1990;97:734-9.

[9] Neuwirth RS, Duran AA, Singer A, MacDonald R, Bolduc L. The endometrial ablator: a new instrument. Obstet Gynecol 1994;83:792- 6 .

[10] Meyer WR, Walsh BW, Grainger DA, Peacock LM, Loffer FD, Steege JF. Thermal balloon and rollerball alation to treat menorrhagia: a multicenter comparison. Obstet Gynecol 1998;92:98-103.

[11] Grainger DA, Tjaden BL, Rowland C, Meyer WR. Thermal balloon and rollerball ablation to treat menorrhagia: two year results of a multicenter, prospective randomized clinical trial. J Am Assoc Gynecol Laparosc 2000;7:175-9.

[12] Loffer FD. Three year comparison of thermal balloon and rollerball ablation in treatment of menorrhagia. J Am Assoc Gynecol Laparosc 2001;8:48-54.

[13] Loffer FD, Grainger D. Five-year follow up of patients participating in a randomized trial of uterine balloon therapy versus rollerball ablation for treatment of menorrhagia. J Am Assoc Gynecol Laparosc 2002;9:429- 35.

[14] van Zon-Rabelink IA, Vleugels MP, Merkus HM, Graaf R. Efficacy and satisfaction rate comparing endometrial ablation by rollerball electrocoagulation to uterine balloon thermal ablation in a randomized controlled trial. Eur $\mathrm{J}$ Obstet Gynecol Reprod Biol 2004;114:97-103.

[15] van Zon-Rabelink IA, Vleugels MP, Merkus HM, Graaf R. Endometrial ablation by rollerball electrocoagulation compared to uterine balloon thermal ablation technical and safety aspects. Eur J Obstet Gynecol Reprod Biol 2003; 110:220 - 3.

[16] Richart RM, Botacini das Dores G, Nicolau SM, Focchi GR, Cordeiro VC. Histologic studies of the effects of circulating hot saline on the uterus before hysterectomy. J Am Assoc Gynecol Laparosc 1999;6:269-73.

[17] Corson SL. A multicenter evaluation of endometrial ablation by Hydro ThermAblator and rollerball for treatment of menorrhagia. J Am Assoc Gynecol Laparosc 2001;8:359-78. 
[18] Goldrath NH. Evaluation of HydroThermAblator and rollerball endometrial ablation for menorrhagia 3 years after treatment. J Am Assoc Gynecol Laparosc 2003;10: 505-11.

[19] Vilos GA. Hysterscopic and nonhysteroscopic endometrial ablation. Obstet Gynecol Clin North Am 2004;31:687- 704.

[20] Cahan WG, Brockunier AJ. Cryosurgery of the uterine cavity. Am J Obstet Gynecol 1967;99:138-53.

[21] Droegemueller W, Greer BE, Makowski EL. Preliminary observations of cryoablation of the endometrium. Am J Obstet Gynecol 1970;107:958-61.

[22] Smith JJ, Fraser J. An estimation of tissue damage and thermal history in the cryolesion. Cryobiology 1974;11: 139-47.

[23] Dubela AJ, Heppard MC, Soderstrom RM, Townsend DM. A randomized study comparing endometrial cryoablation and rollerball electroablation for treatment of dysfunctional uterine bleeding. J Am Assoc Gynecol Laparosc 2003;10: 17- 26.

[24] Townsend DE, Dubela AJ, Wilkes MM. Durability of treatment effects after endometrial cryoablation versus rollerball electroablation for abnormal uterine bleeding: two year results of a multicenter randomized trial. Am J Obstet Gynecol 2003;188:699-701.

[25] Cooper J, Gimpelson R, Laberge P, Galen D, Garza-Leal JG, Scott J, et al. A randomized, multicenter trial of safety and efficacy of the NovaSure System in the treatment of menorrhagia. J Am Assoc Gynecol Laparosc 2002;9:418- 28.
[26] Bongers MY, Bourdrez P, Mol BWJ, Heintz APM, Brolmann HA. Randomized controlled trial of bipolar radio-frequency endometrial ablation and balloon endometrial ablation. $\mathrm{Br}$ J Obstet Gynaecol 2004;111:1005-102.

[27] Sharp NC, Cronin N, Feldberg I, Evans M, Hodgson D, Ellis S. Microwaves for menorrhagia: a new fast technique for endometrial ablation. Lancet 1995;346:1003-4.

[28] Cooper JM, Anderson TL, Fortin CA, Jack SA, Plentl MB. Microwave endometrial ablation versus rollerball electroablation for menorrhagia: a multicenter randomized trial. $J$ Am Assoc Gynecol Laparosc 2004;11:394- 403.

[29] Cooper KG, Bain C, Parkin D. Comparison of microwave endometrial ablation and transcervical resection of the endometrium for treatment of heavy menstrual loss: a randomized trial. Lancet 1999;354:1859-63.

[30] Bain C, Cooper KG, Parkin DE. Microwave endometrial ablation versus endometrial resection: a randomized controlled trial. Obstet Gynecol 2002;99:983-7.

[31] Fortin CA, Fontaine J. Microwave endometrial ablation compared with pretreatment options. J Am Assoc Gynecol Laparosc 2002;9:S19.

[32] Della Badia CR. Essure insertion after microwave ablation. J Am Assoc Gynecol Laparosc 2005;12:S118.

[33] Glazerman LR. Essure sterilization after microwave ablation. J Am Assoc Gynecol Laparosc 2005;12:S118. 